\title{
Morphological characteristics of preimplantation stage endometrium in the rhesus monkey
}

\author{
Debabrata Ghosh, Anindita Roy, \\ Jayasree Sengupta ${ }^{1}$ and Elisabeth Johannisson ${ }^{2}$
}

Department of Physiology, All India Institute of Medical Sciences, New Delhi 110029 , India and ${ }^{2}$ Clinic of Sterility and Gynaecological Endocrinology, Department of Obstetrics and Gynaecology, University Hospital, 32 Boulevard de la Cluse, 1211 Geneva 4, Switzerland

${ }^{1}$ To whom correspondence should be addressed

The morphological characteristics of endometrium on day 6 after ovulation of conception (group 1) and non-fecund, menstrual (group 2) cycles have been studied in the rhesus monkey $(n=30)$. A conception cycle was distinguished by the presence of a developmentally normal, age-stage-synchronized embryo. Thus, $78 \%$ of the mated cycles $(n=18)$ yielding synchronous embryos (12 zona-encased and two zonafree blastocysts) were used for this study. On day 6 after ovulation, no significant changes in the serum concentrations of oestrogen and progesterone were seen in conception cycles $(n=14)$ compared with the non-mated, normal ovulatory cycles $(n=12)$. Morphometric analyses revealed that on day 6 of gestation $(n=8)$, endometrium differed from the corresponding non-mated luteal phase $(n=7)$ with significant increases in epithelial mitosis $(P<0.01)$, height of glandular epithelium $(P<0.05$ ), volume ratio of gland cell to gland $(P<0.03)$, degree of pseudostratification $(P<0.02)$, and higher frequency of supranuclear, adluminal accumulation of vacuoles in gland cells $(P<0.05)$. The degree of stromal oedema was higher $(P<0.02)$ in fecund cycles but there was no change in venular diameter. In a separate set of experiments, estimates of tissue vascular response revealed a higher $(P<0.02)$ endometrial extravascular albumin space on the same day of gestation; there were no differences, however, in endometrial blood volume, or in the number of von Willebrand antigen-positive capillaries and small vessels between the two groups (group 1, $n=6$; group 2, $n=5$ ). The overall results of the present study together with our earlier reports support the hypothesis that differential changes occur in luteal phase endometrium functionalis in the presence of preimplantation stage blastocyst in the rhesus monkey. Key words: endometrium/morphology/preimplantation/rhesus monkey/von Willebrand protein

\section{Introduction}

Initiation of implantation is dependent upon synchrony between endometrial receptivity and embryonic development. While it has been known for some time that premature as well as retarded development of the luteal phase endometrium is incompatible with implantation (Dallenbach-Hellweg, 1987), our understanding about the nature of endometrial receptivity for implantation in primates is incomplete (Johannisson, 1991).

Endometrial sensitization during the preimplantation period is regulated primarily by the hormonal milieu within the tissue bed. None the less, we postulate that functional differentiation of the endometrium in the primate in the presence of a preimplantation stage blastocyst is not identical to that occurring at a comparable time of the luteal phase during a non-conception cycle, and that this difference occurs despite the lack of significant changes in the peripheral sex hormonal profiles as reported for women and rhesus monkeys (Hendrickx and Enders, 1980; Ghosh and Sengupta, 1989a). There are biochemically distinguishable features in preimplantation stage endometrium of the rhesus monkey. These include suppression of acid hydrolytic enzymes, enhancement of alkaline phosphatase and higher retention of nuclear receptors for oestrogen and progesterone in preimplantation stage endometrium compared with secretory endometrium at a corresponding stage of the luteal phase from the non-fecund, menstrual cycle (Ghosh and Sengupta, 1988a,b; Sengupta et al. , 1988). While the functional relevance of these changes in pre-nidatory endometrium may appear obvious, no morphological associations are known. In the present study, our aim was to examine the morphological characteristics of preimplantation stage endometrium, and of luteal phase endometrium of the nonfecund cycle, collected from rhesus monkeys on day 6 after ovulation.

Because a traditional histological study does not provide precise quantitative information, and in order to detect possible subtle differences in morphological characteristics, morphometric estimates of the tissues were also obtained. A literature review suggested that vascular prominence and oedematous reaction in peri-implantation stage endometrium would be expected (Foss et al., 1958; Mazur et al., 1989). Hence, in addition to histometric analysis, the degree of endometrial vascularity in terms of blood volume and the extravascular volume were also estimated by using a radioisotopic method (Bill, 1968; Milligan and Mirembe, 1984) to obtain an objective assessment and to circumvent the chance of artefactual estimation of oedema in histological preparations. Moreover, routine histological examination is often not sufficient to study the capillary plexus and small vessels in the tissue. Immunohistochemical staining for factor VIII-related antigen, on the other hand, has been shown to be an effective method for selective examination of vascular endothelial cells (Thorgeirsson and Robertson, 1978; Martin et al., 1987). Hence, this technique has also been applied in the present study. 


\section{Materials and methods}

\section{Animals}

Healthy, adult female and male rhesus monkeys (Macaca mulatta) of proven fertility were used in this study. The details of animal handling, their maintenance, mating schedule and record keeping in the Primate Research Facility of the All India Institute of Medical Sciences, have been described earlier (Ghosh and Sengupta, 1988a,b; Sengupta et al., 1989). In brief, monkeys were individually caged in rooms having access to natural light. They were fed on a standard pellet diet supplemented with fresh fruit, soaked gram, peanuts and water ad libitum. This study conformed to the ethical standards of animal welfare (Howard-Jones, 1985).

The vaginal swab from each female monkey was checked daily. A total of 34 females showing two consecutive cycles of normal length (26-32 days) were initially selected for this study. Four females did not ovulate and were excluded subsequently. The remaining monkeys $(n=30)$ were assigned to two treatment groups. Monkeys in group $1(n=18)$ were caged with proven fertile males during cycle days 8-16 of their menstrual cycles. The occurrence of insemination was assessed by daily microscopic examination of vaginal swabs. Monkeys in group $2(n=12)$ were not caged with males. Peripheral venous blood samples from all monkeys were collected twice daily during the mating period, and the sera were separated and used to determine the profiles of oestrogen and progesterone according to methods described earlier (Ghosh and Sengupta, 1989a,b).

\section{Tissue sampling}

The procedure for endometrial tissue sampling and the criteria for selecting samples have been described by Sengupta et al. $(1988,1989)$. Briefly, the dating of endometrial samples was done on the basis of ovulation, whereby $24 \mathrm{~h}$ after the peak value of serum oestrogen was taken as the day of ovulation (day 0 ). Endometrial tissue samples were collected on day 6 after ovulation by performing laparotomy and fundal hysterotomy following ketamine $(10 \mathrm{mg} / \mathrm{kg}$; Vetlar, Parke Davis, Bombay, India) immobilization. Prior to tissue collection, the entire reproductive tract was flushed with sterile, Earle's balanced salt solution (EBSS, Gibco-BRL, New York, NY, USA), pH 7.4, as described by Sengupta et al. (1988, 1989). The main purpose of the flushing was to obtain a preimplantation stage embryo, the presence of which served as the criterion for considering a mated ovulatory cycle as a conception cycle. Several reports show that an approximate synchronization exists between estimated age relative to ovulation and the developmental stage of the embryo in monkeys (see Bavister et al., 1983; Sengupta et al., 1989). Accordingly, only endometrial samples from mated, ovulatory cycles that yielded blastocyst stage embryos on day 6 after ovulation were analysed in the present study. For monkeys in group 2, laparotomy was performed on day 6 after ovulation, the presence of a fresh corpus luteum was checked, the entire reproductive tract was flushed as described above, and endometrial tissue samples were collected. For both groups of monkeys, age relative to ovulation was determined from the serum concentration of oestrogen as described above.

\section{Tissue processing and microscopic examination}

Endometrial tissue samples from the fundal region of the uterine corpus were collected in fresh, ice-cold EBSS, washed in cold medium to remove adhering blood, and immediately processed. Tissue samples for light microscopy were fixed in Bouin's solution, dehydrated through graded alcohol and embedded in paraffin wax. Tissue sections $(6 \mu \mathrm{m})$ were stained with haematoxylin and eosin. Endometrial samples were also fixed in ice-cold, $3 \%(v / v)$ glutaraldehyde in sodium cacodylate buffer $(0.1 \mathrm{~mol} / \mathrm{l}, \mathrm{pH} 7.4)$ and post-fixed in osmium tetroxide. Fixed tissues were dehydrated through graded ethanol and embedded in epoxy resin (EMbed 812, Electron Microscopic Sciences, Fort Washington, PA, USA). The details are given elsewhere (Sengupta et al., 1990; Ghosh et al., 1992). Sections (1-2 $\mu \mathrm{m})$ were cut and stained with $1 \%$ Toluidine Blue. The paraffin and semi-thin sections were examined in a Leitz Orthomat microscope.

\section{Morphometric analysis}

Morphometric measurements of the functionalis zone (zones I-III) of the endometrial samples obtained from monkeys of group $1(n=8)$ and group $2(n=7)$ were made using histometric and stereological methods as described by Johannisson $e t$ al. (1982, 1987), Li et al. (1988) and Ghosh et al. (1992). Histometric measurements included cell counting, linear measurement, and semi-quantitative measurement with a four-point scoring system from $0-3(0=$ absent, $1=$ mild, $2=$ moderate, 3 = marked). The multipurpose test described by Rohr et al. (1978) was used in estimating the volume densities of epithelium in reference to the whole endometrium, gland cell in reference to the whole gland, and gland lumen with reference to the whole endometrium.

The morphometric indices measured in the glandular epithelial compartment were: (i) number of glands per $\mathrm{mm}^{2}$ (Gl), (ii) volume fraction of endometrium occupied by glands (G2), (iii) average diameter of glands (G3), (iv) maximum height of gland cell (G4), (v) volume fraction of gland occupied by gland cell (G5), (vi) number of mitoses per 1000 gland cells (G6), (vii) number of vacuolated cells per 1000 gland cells (G7), (viii) number of supranuclear vacuoles per 100 gland cells (G8), (ix) extent of pseudostratification in gland cells (G9), (x) volume fraction of endometrium occupied by glandular lumen (G10), and (xi) amount of secretion in glandular lumen (G11). In the stromal compartment, the histometric indices measured were: (i) diameter of venular capillary (S1); (ii) degree of stromal oedema (S2); and (iii) stromal cell mitosis (S3).

\section{Immunohistochemistry of Factor VIII-related antigen}

Immunohistochemical staining for Factor VIII-related (von Willebrand; vW) antigen was performed according to the method described by Martin et al. (1987). Briefly, tissue sections were deparaffinized and hydrated through graded alcohol to phosphate-buffered saline (PBS). Sections were trypsinized $(0.15 \% \mathrm{w} / \mathrm{v}$; Sigma Chemical Co., St Louis, MO, USA) and endogenous peroxidase activity was then quenched with $0.3 \%$ hydrogen peroxide in methanol. The sections were blocked with normal goat serum (Vector Laboratory, Burlingame, CA, USA) 
followed by incubation with primary antibody (rabbit antivon Willebrand; Dakopatts, Glostrup, Denmark), 1:20 at room temperature for $30 \mathrm{~min}$. After incubation sections were washed and incubated with biotinylated goat anti-rabbit IgG, 1:200 (Vector Laboratory). The sections were visualized using the $\mathrm{ABC}$ kit (Vector Laboratory) and developed in freshly made diaminobenzedine tetrahydrochloride (Sigma Chemical Co.), and hydrogen peroxide according to the protocol provided by the manufacturer. Stained sections were analysed by light microscopy to estimate the numbers of von Willebrand antigen-positive capillaries per $\mathrm{mm}^{2}$, and the degree of immunostaining based on a semi-quantitative scoring scale as described above.

\section{Endometrial blood volume and permeability}

The estimates of vascularity in endometrium functionalis, in terms of tissue blood volume and plasma equivalent extravascular albumin volume in both groups (group $1, n=6$; group 2, $n=5$ ) were determined by using the radioisotopic method as described by Milligan and Mirembe (1984). Peripheral blood samples were collected from the saphenous vein on the morning of the day of laparotomy and tissue collection. A plasma aliquot was stored at $-20^{\circ} \mathrm{C}$ for estimation of oestradiol and progesterone. Red blood cells (RBCs) were isolated using acid-citrate dextrose (Terumo Corporation, Tokyo, Japan) and labelled with $\mathrm{Na}_{2}{ }^{51} \mathrm{CrO}_{4}$ (400 Ci/g; New England Nuclear, Boston, MA, USA) and washed three times with $0.154 \mathrm{M}$ isotonic saline to remove free radioactivity (Lewis and Yin, 1986). Human serum albumin (HSA) was iodinated by the Iodogen method, and free iodine was separated by Sephadex G25 minicolumn filtration (Fraker and Speck, 1978). About 30 min prior to the actual tissue collection by laparotomy, monkeys were immobilized as described above and RBCs labelled with chromium radioisotope $\left({ }^{5 l} \mathrm{Cr}\right)$ ( $1 \mathrm{ml}$ containing $\sim 100 \mu \mathrm{Ci}{ }^{51} \mathrm{Cr}$ per $\mathrm{kg}$ body weight) along with $10 \mu \mathrm{Ci}$ radioiodine-labelled HSA ([ $\left.\left.{ }^{125} \mathrm{I}\right] \mathrm{HSA}\right)$ were slowly injected into the median cubital vein and blood samples were collected on EDTA from the contralateral vein at different time intervals. The collection of blood samples, isolation and labelling of red blood cells with ${ }^{51} \mathrm{Cr}$ and injection of labelled red cells along with $\left[{ }^{125} \mathrm{I}\right] \mathrm{HSA}$ were performed following the procedure described for human subjects (Lewis and Yin, 1986). All the steps were performed under aseptic and pyrogen-free conditions avoiding extravasation. In both groups, the reproductive tract was flushed with sterile EBSS and endometrial tissue collected as described above.

The flushings from mated monkeys of group 1 were examined quickly under a stereozoom for the presence of a blastocyst to confirm a stage-synchronized conception cycle.

Radioactivity in endometrium, blood and plasma were determined in two channels of an LKB gamma-spectrometer with appropriate corrections for spillover between the two isotopes. More than $95 \%$ [ $\left.{ }^{125} \mathrm{I}\right] \mathrm{HSA}$ as well as ${ }^{51} \mathrm{Cr}$ labelling of red blood cells remained undegraded during the time of tissue collection, which was about 30 min after the infusion of radiolabelled RBCs. This timing was adjusted on the basis of initial determination of the optimal time required for achieving the steady state of distribution of ${ }^{51} \mathrm{Cr}$-labelled $\mathrm{RBCs}$ in the circulation showing minimum degradation. Tissue blood volume $(\mu \mathrm{l} / \mathrm{g})$ was estimated
Table I. Serum concentrations of oestrogen and progesterone on day 6 after ovulation in conception (group 1) and non-fecund, menstrual (group 2) cycles

\begin{tabular}{|c|c|c|c|}
\hline \multirow[t]{2}{*}{ Hormone } & \multicolumn{2}{|c|}{ Estimate (mean \pm SEM) } & \multirow{2}{*}{$\begin{array}{l}\text { Comparison between } \\
\text { groups }(\% \text { increase } \\
\text { in group } 1)^{\mathrm{a}}\end{array}$} \\
\hline & $\begin{array}{l}\text { Group 1 } \\
(n=14)\end{array}$ & $\begin{array}{l}\text { Group 2 } \\
(n=12)\end{array}$ & \\
\hline $\begin{array}{r}\text { Oestrogen } \\
(\mathrm{pmol} / \mathrm{l})\end{array}$ & $376.5 \pm 25.8$ & $328.8 \pm 26.2$ & 14.5 \\
\hline $\begin{array}{l}\text { Progesterone } \\
(\mathrm{nmol} / \mathrm{l})\end{array}$ & $16.8 \pm 3.7$ & $14.2 \pm 2.8$ & 18.3 \\
\hline
\end{tabular}

${ }^{\mathrm{a}}$ Values were not significantly different between groups 1 and 2 .

from the relative concentration of ${ }^{51} \mathrm{Cr}$ in blood and tissue samples on the assumption that the tissue and systemic haematocrits were identical. The apparent plasma equivalent extravascular albumin space $(\mu \mathrm{l} / \mathrm{g})$ was determined according to Milligan and Mirembe (1984).

\section{Statistical analyses}

Statistical analyses of the histometric, stereological and immunohistometric measurements were done using $t$-test, and modified $t$-test with the inclusion of a correction for continuity when required. Student's $t$-test was employed for the comparison of estimates of blood volume and of apparent plasma equivalent extravascular albumin volume and of peripheral steroid hormones. The probability level of $P=0.05$ was taken as the limit of significance.

\section{Results}

Out of 18 mated, ovulatory cycles, an embryo was not retrieved in two, and in an additional two the embryos were found to be abnormal. The endometrial samples collected in these four mated cycles were not used. Embryos recovered on day 6 after ovulation from the remaining mated, ovulatory cycles were developmentally synchronous; they were either zona-encased blastocysts $(n=12)$ or zona-free blastocysts $(n=2)$. Hence, $78 \%$ of mated cycles yielded synchronous embryos. Table I shows that although the concentrations of serum oestradiol and progesterone on day 6 after ovulation in conception cycles (group 1) tended to be slightly higher than in non-fecund cycles (group 2), the differences were not statistically significant.

Table II shows the results of the morphometric analyses of endometrial glands on day 6 after ovulation of synchronous conception cycles (group $1 ; n=8$ ) and normal, non-fecund ovulatory cycles (group $2 ; n=7$ ). Clearly, the glandular compartment of the endometrium during the preimplantation period differed from the corresponding stage normal, luteal phase endometrium. Significant changes were seen in epithelial mitoses $(P<0.01)$, the height of the glandular epithelium $(P<0.05)$, the volume ratio of gland cell to gland $(P<0.03)$, and the degree of pseudostratification $(P<0.02)$. Despite an apparent increase of $\sim 34 \%$ in conception cycles, the average diameter of glands was not significantly different from that of non-fecund cycles. The frequency of supranuclear, adluminal accumulation of 
Table II. Morphometric analysis of endometrial glands

\begin{tabular}{|c|c|c|c|}
\hline \multirow[t]{2}{*}{ Index } & \multicolumn{2}{|c|}{ Estimate $($ mean \pm SEM) } & \multirow{2}{*}{$\begin{array}{l}\text { Probability of significant } \\
\text { difference between groups }\end{array}$} \\
\hline & $\begin{array}{l}\text { Group } 1^{\mathrm{a}} \\
(n=8)\end{array}$ & $\begin{array}{l}\text { Group 2a } \\
(n=7)\end{array}$ & \\
\hline Number of glands $/ \mathrm{mm}^{2}(\mathrm{G} 1)$ & $40.3 \pm 6.4$ & $34.1 \pm 5.7$ & \\
\hline $\begin{array}{l}\text { Volume fraction of } \\
\text { endometrium occupied } \\
\text { by gland (\%) (G2) }\end{array}$ & $45.5 \pm 2.5$ & $38.7 \pm 2.0$ & \\
\hline $\begin{array}{l}\text { Average diameter of } \\
\text { gland }(\mu \mathrm{m})(\mathrm{G} 3)\end{array}$ & $158.0 \pm 20.2$ & $118.0 \pm 12.1$ & \\
\hline $\begin{array}{l}\text { Maximum gland cell } \\
\text { height }(\mu \mathrm{m})(\mathrm{G} 4)\end{array}$ & $40.0 \pm 3.0$ & $30.0 \pm 2.6$ & $P<0.05$ \\
\hline $\begin{array}{l}\text { Volume fraction of } \\
\text { gland occupied by } \\
\text { gland cell (\%) (G5) }\end{array}$ & $68.5 \pm 2.9$ & $58.9 \pm 1.8$ & $P<0.03$ \\
\hline $\begin{array}{l}\text { Mitosis } / 1000 \text { gland } \\
\text { cells (G6) }\end{array}$ & $5.9 \pm 0.7$ & $1.9 \pm 0.4$ & $P<0.01$ \\
\hline $\begin{array}{l}\text { Number of vacuolated } \\
\text { cells/1000 gland cells } \\
\text { (G7) }\end{array}$ & $166.1 \pm 9.3$ & $179.9 \pm 23.8$ & \\
\hline $\begin{array}{l}\text { Number of supranuclear } \\
\text { vacuoles } / 100 \text { gland } \\
\text { cells (G8) }\end{array}$ & $5.5 \pm 0.8$ & $2.2 \pm 1.1$ & $P<0.05$ \\
\hline $\begin{array}{l}\text { Degree of pseudostratification } \\
\text { of gland cells (score) (G9) }\end{array}$ & $1.3 \pm 0.1$ & $0.7 \pm 0.1$ & $P<0.02$ \\
\hline $\begin{array}{l}\text { Volume fraction of } \\
\text { endometrium occupied } \\
\text { by gland lumen (\%), } \\
\text { (G10) }\end{array}$ & $22.0 \pm 2.0$ & $18.2 \pm 1.4$ & \\
\hline $\begin{array}{l}\text { Amount of secretion in } \\
\text { gland lumen (score) (G11) }\end{array}$ & $1.6 \pm 0.1$ & $1.3 \pm 0.2$ & \\
\hline
\end{tabular}

asee Table I for group definitions.

vacuoles was higher $(P<0.05)$ in glands of preimplantation stage endometrium. However, there was no significant change in lumen density and secretory activity of glands between the two experimental groups.

Figure 1 shows some of the characteristic features in the glandular compartment of endometrial samples from non-fecund and conception cycles. In specimens from conception cycles nuclei were found to be more frequently basifixed in the glandular epithelium, with obvious cell crowding and pronounced bosselation at the luminal borders. Intra-epithelial lymphoid cells (IELs) were more frequently seen in glandular and luminal epithelium of endometrium from conception cycles. Also, IELs in the luminal epithelium of conception cycles were generally more numerous at sites adjacent to pronounced oedema in the subepithelium (Figure 2). However, no immunohistochemical analysis was performed in this regard.

Histometric analysis of the stromal compartment showed that there was a clear-cut increase in the oedematous reaction in the endometrium during the preimplantation period compared with the corresponding luteal stage, but no change could be detected in venule diameter nor in stromal cell mitoses between the two groups (Table III). Overall, the stromal oedema in non-fecund endometrium was at an early stage (around 1 in the semiquantitative scoring scale). While in conception cycles this was in the range of a moderate score. In conception cycles, a very high degree of oedema and vessel congestion was occasionally found to be present in a focused manner in immediate subluminal zones of endometrium (Figures 2 and 3).

Accentuation of oedema in conception cycles was found to be mainly confined to the superficial zones of endometrium functionalis, primarily zone II and upper strata of zone III. The results obtained in experiments of radioisotopic determination of the endometrial vascular response revealed that there was an increase $(P<0.02)$ in the apparent extravascular space for iodo-albumin, with no change in blood volume in endometrium from conception cycle as compared to menstrual cycle (Table IV). As to the number of endometrial capillaries and small vessels reacting positively to the von Willebrand antigen, the immunohistometric assessment did not reveal any difference between the two groups (Table IV).

\section{Discussion}

The present report documents the morphological characteristics of endometrial samples collected on day 6 after ovulation from proven, synchronous conception cycles and from non-fecund, normal menstrual cycles in the rhesus monkey. The results suggest that monkey endometrium during the preimplantation period displays subtle but discernible changes when compared with luteal phase endometrium from the non-fecund, ovulatory cycle.

The available literature in this regard is sparse. Foss et al. 

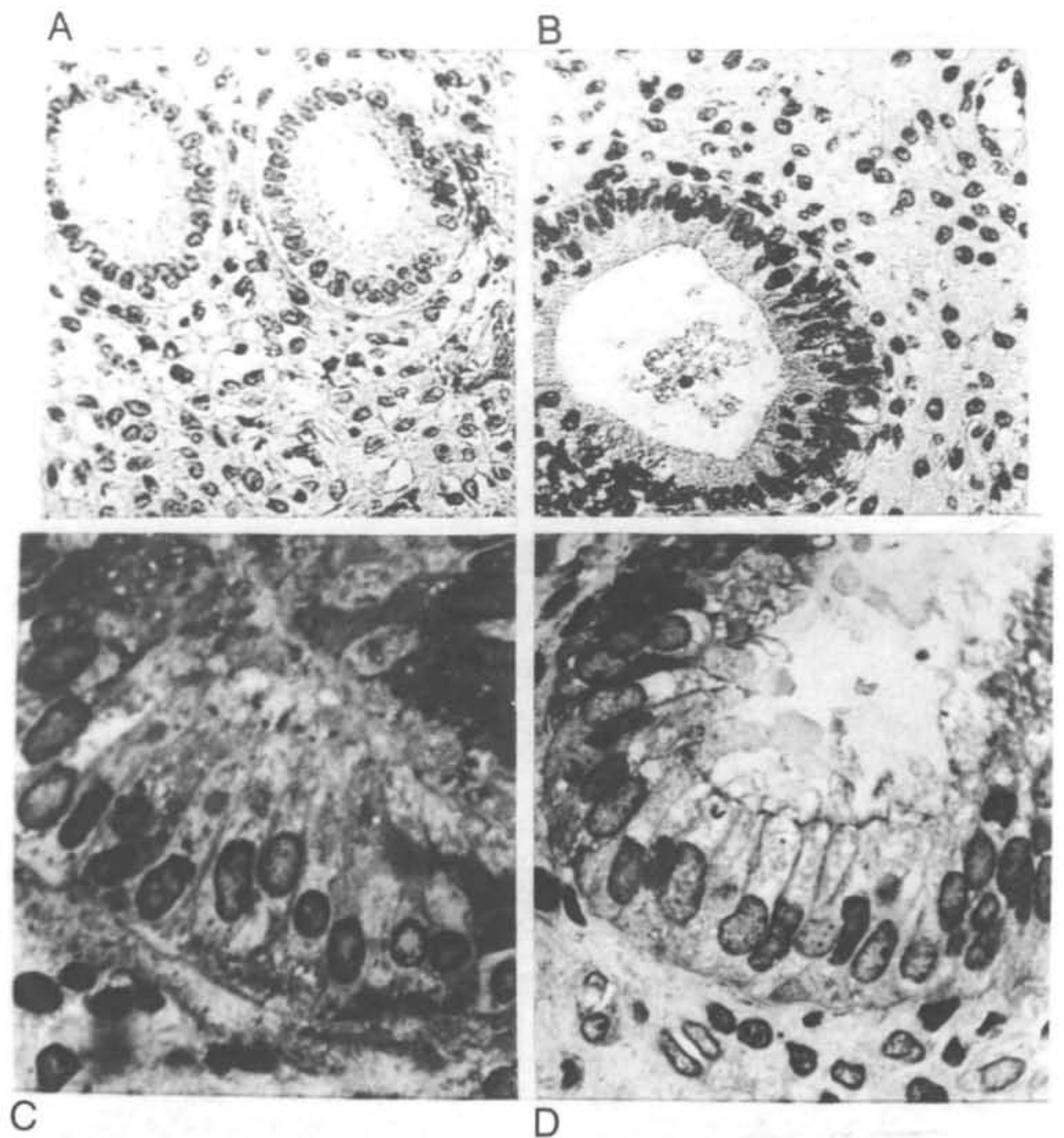

Fig. 1. Glands in endometrium functionalis on day 6 after ovulation from non-mated (A, C), and conception (B, D) cycles of rhesus monkeys. In non-mated cycles [A, haematoxylin and eosin $(\mathrm{H}-\mathrm{E}) \times 200 ; \mathbf{C}$, Toluidine Blue, $\times 540$ ] round glands are seen with supranuclear and subnuclear vacuolation in gland epithelium. The stroma is slightly oedematous with typical vesicular stromal nuclei. In conception cycle $(\mathbf{B}, \mathrm{H}-\mathrm{E}, \times 220 ; \mathbf{D}$, Toluidine Blue, $\times 500)$, endometrial glands show pronounced crowding of basifixed nuclei, clear cytoplasm and blunt-ended cytoplasmic projections into the lumen; the stromal matrix is markedly oedematous.

(1958) indicated that the vascular prominence together with increased blood flow and associated oedema were important features in the endometrium of a human conception cycle. In the present study, the occurrence of increased oedema in the preimplantation endometrium was confirmed. A reappraisal of the report by Hertig (1964) reveals that the degree of oedema on day 6 after ovulation in a conception cycle in the human may be marginally higher than the oedema score on the same day after ovulation in a normal menstrual cycle. In a recent study, Mazur et al. (1989) also observed that stromal oedema and vascular congestion are the only consistent, histologically discernible endometrial changes in conception cycles of the human; however, endometrial samples were collected in their study at somewhat later time-points than in the present study. The estimates of plasma equivalent extravascular volume in the present study indicate that higher vascular permeability is a likely cause of increased oedema in pre-nidatory endometrium, with no significant change in tissue blood volume as measured by radioisotope-labelled red blood cells. The increase in oedema in preimplantation stage endometrium in the rhesus monkey could be a direct or indirect consequence of a blastocyst-derived factor, as suggested by Ferenczy (1987). As shown in our previous study, the steroid milieu in the endometrial tissue bed is marginally altered on day 6 of gestation, compared with day 6 luteal phase in non-fecund cycles (Ghosh and Sengupta, 1989a). It is not known, however, if these changes are causally associated. The regulation of capillary permeability is a multifactorial process, in which the local steroidal milieu plays an important role. Conversely, it is also possible that an increase in vascular permeability itself can alter the steroidal milieu, since albumin functions as a high-capacity, low-affinity binding protein of steroids, including oestrogen (Finn and Porter, 1975).

Some important additional points on the technical aspects of the above observation should be considered. It should be noted 

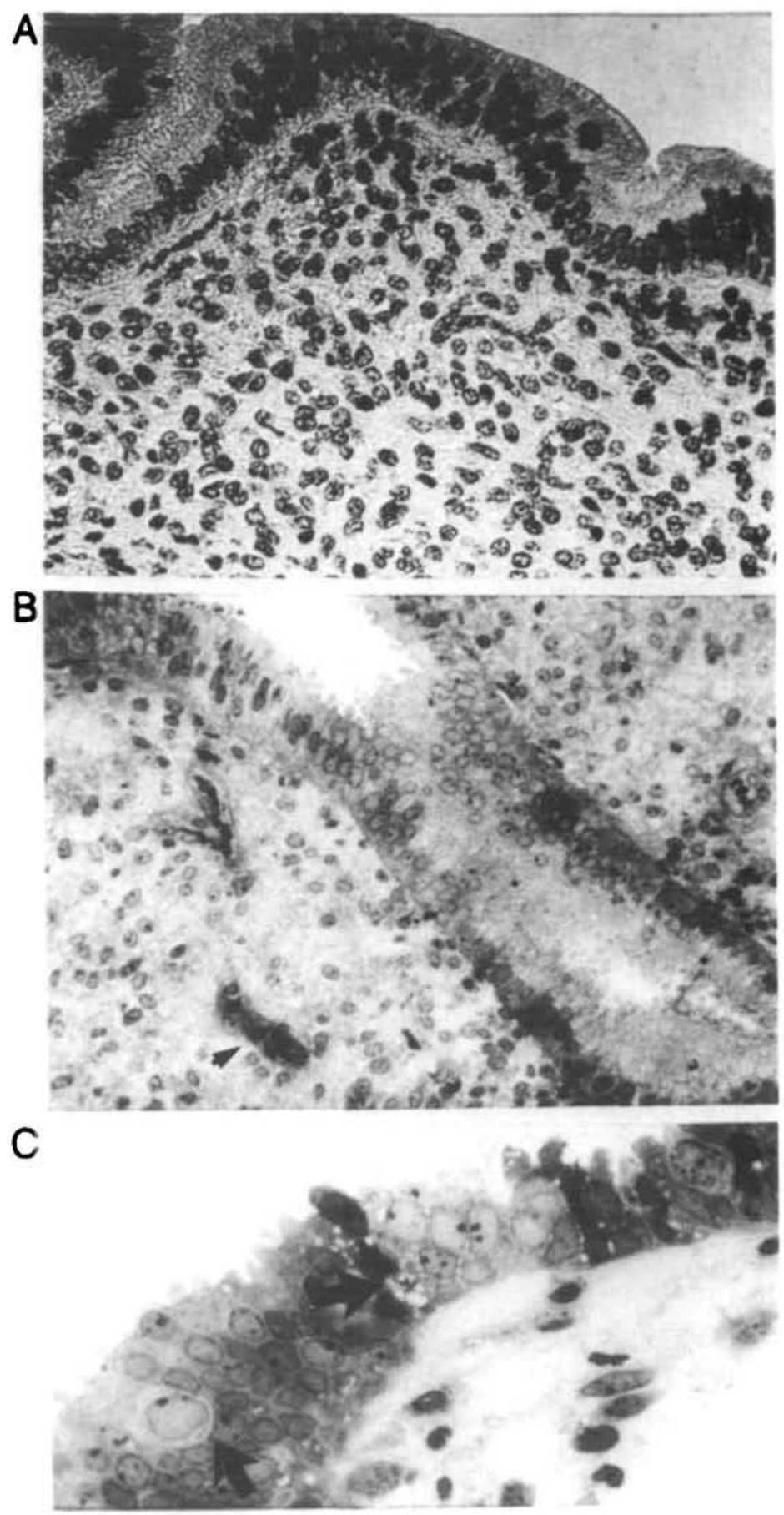

Fig. 2. Surface epithelium with glandular invaginations from the superficial zones of endometrial samples collected on day 6 after ovulation from non-mated $(A, \times 260)$, and conception $(B, \times 210$; C, $\times 460)$ cycles of rhesus monkeys. In the upper functionalis region of endometrium from conception cycles (B and $\mathbf{C})$ there were large numbers of small pinopods in the apical surface, intraepithelial lymphocytes (arrows) and marked vascular congestion (arrowhead), along with oedema.

that the radioisotopic measurements of vascular changes are based on the assumption that tissue and venous haematocrit values are identical (Lewis and Yin, 1986). However, the relationship between these haematocrits may change as a result of altered vascular permeability and blood flow (Hay and Movat. 1979).
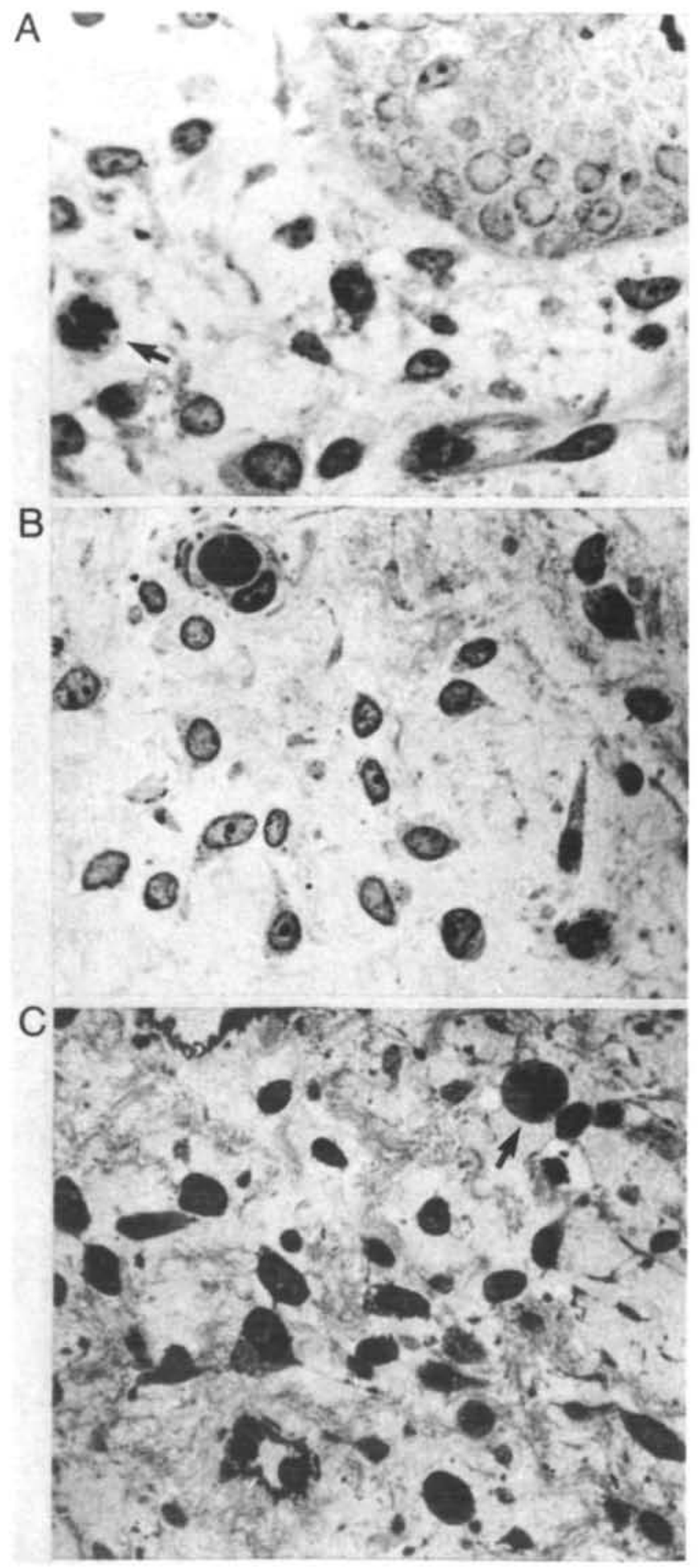

Fig. 3. Endometrium functionalis on day 6 of gestation. Distinctive oedema is seen surrounding a gland in the superficial stroma (A). In the lower zones $(\mathbf{B}, \mathbf{C})$ a decreasing magnitude of oedema along with increased reticular appearance of the matrices was observed. Stromal cell mitoses (arrow) and granulocytes are evident. Toluidine Blue stain. $\times 510$.

Secondly, the endometrial vascular response is thought to be higher in regions close to an implanting blastocyst. In the present study. the pooled estimate of sedema observed in fundal endometrium must have been attenuated by less affected tissue 


\begin{tabular}{lll}
\hline Table III. Morphometric analysis of endometrial stroma & \\
\hline $\begin{array}{l}\text { Index } \\
\text { Estimate (mean } \pm S E M)\end{array}$ & $\begin{array}{l}\text { Group } 1^{\mathrm{a}} \\
(n=8)\end{array}$ & $\begin{array}{l}\text { Group } 2^{\mathrm{a}} \\
(n=7)\end{array}$ \\
\hline $\begin{array}{l}\text { Diameter of venular } \\
\text { capillary ( } \mu \mathrm{m})(\mathrm{S} 1)\end{array}$ & $19.8 \pm 2.8$ & $18.3 \pm 3.3$ \\
$\begin{array}{l}\text { Mitosis } / 1000 \text { stromal } \\
\text { cells (S2) }\end{array}$ & $3.4 \pm 0.4$ & $2.3 \pm 0.6$ \\
$\begin{array}{l}\text { Amount of oedema } \\
\text { (score) (S3) }\end{array}$ & $1.6 \pm 0.2$ & $0.9 \pm 0.1$ \\
\hline
\end{tabular}

${ }^{\mathrm{a}}$ See Table I for group definitions.

\begin{tabular}{|c|c|c|c|}
\hline \multirow[t]{2}{*}{ Index } & \multicolumn{2}{|c|}{ Estimate $($ mean \pm SEM) } & \multirow{2}{*}{$\begin{array}{l}\text { Probability of significant } \\
\text { difference between groups }\end{array}$} \\
\hline & $\begin{array}{l}\text { Group } 1^{\mathrm{a}} \\
(n=6)\end{array}$ & $\begin{array}{l}\text { Group 2a } \\
(n=5)\end{array}$ & \\
\hline $\begin{array}{l}\text { Extravascular } \\
\text { albumin volume } \\
(\mu \mathrm{l} / \mathrm{g})\end{array}$ & $20.8 \pm 1.3$ & $15.7 \pm 1.2$ & \multirow[t]{3}{*}{$P<0.02$} \\
\hline $\begin{array}{l}\text { Blood volume } \\
(\mu \mathrm{l} / \mathrm{g})\end{array}$ & $27.3 \pm 3.6$ & $22.0 \pm 2.9$ & \\
\hline $\begin{array}{l}\text { Number of } \\
\text { von Willebrand } \\
\text { antigen positive } \\
\text { vessels } / \mathrm{mm}^{2}\end{array}$ & $40.4 \pm 3.6$ & $39.4 \pm 4.6$ & \\
\hline
\end{tabular}

${ }^{a}$ See Table I for group definitions.

of more peripheral areas. Indeed, extremely high scores of oedema were occasionally found to be focally concentrated in conception cycles. Thirdly, the uterine flushing procedure may also influence endometrial blood flow and permeability directly as well as the morphology. However, this factor is likely to be identical for both groups. Fourthly, endometrial oedema, in any case, increased rapidly during days 5-8 after ovulation of the normal menstrual cycle (Noyes et al., 1950; Bartelmez et al., 1951; Hertig, 1964; Brenner and Maslar, 1988). Thus, the observed increase in oedema in pre-nidatory endometrium may not have high potential value for routine diagnosis. Nevertheless, it may be a physiologically significant endometrial reaction required for blastocyst implantation in the primate.

The von Willebrand factor is a large glycoprotein of complex, multimeric structure held together by disulphide bonds (Hoyer, 1981). In endothelial cells, Factor VIII-related antigen is concentrated in organelles called Weibel-Palade bodies (Wagner et al., 1982), and hence vascularity can be studied better by immunohistochemical staining for von Willebrand factor, as compared to haematoxylin-eosin staining (Martin et al., 1987). It is now being suggested that endothelial cells of the capillary plexus may possess steroid hormone receptors, and the expression of von Willebrand antigen in these cells may be regulated by the steroidal milieu (Colburn and Buonassisi, 1978; Johannisson, 1986; Wang et al. , 1992). Though Foss et al. (1958) emphasized vascular prominence, we did not obtain any change in the expression of von Willebrand antigen by endothelial cells of capillaries and small vessels of the functional layer in the prenidatory stage endometrium. Standardized quantitative assessment may, however, yield additional information in this respect.

Using human endometrial biopsy samples from normal menstrual cycles, it has been recently demonstrated that the accumulation of leukocytes, especially of the suppressor-cytotoxic $\mathrm{T}$ cell subset $(\mathrm{CD} 8+$ ) is evident in the endometrium on day 7 after the ovulatory luteinizing hormone (LH) peak; in contrast, no change in the population of CD56 $+\mathrm{T}$ cell subset could be seen (Klentzeris et al., 1992). The latter cell type has been found to be phenotypically related to, but not identical with, endometrial large granulated lymphocytes (see Loke et al., 1993). In the present study we have observed that there was an increased accumulation of lymphoid cells within the stroma and also in the epithelial cell compartment along with the presence of granulated lymphocytes in endometrial samples from conception cycles. It would be interesting to study systematically, using immunohistochemical and cytochemical techniques, the potential role of peripheral mucosa-associated lymphoid tissue in the endometrium, both at the site of nidation in the process of cell-matrix reorganization and in relation to immunological adjustments (Morris et al., 1985) necessary for successful implantation.

Using a semi-quantitative scale, Hertig (1964) showed that glandular changes in the endometrium are the early distinguishing events in a human conception cycle. However, one may fail to detect these changes (Arronet et al., 1973; Wentz et al., 1986; Mazur et al., 1989) because of technical constraints of using biopsy samples, as discussed by Mazur et al. (1989). The results of the present study clearly indicated that distinctive changes occurred in the glandular epithelium in the conception cycle of the rhesus monkey. On the one hand, the cellularity of glands 
was enhanced, in association with increased number of mitoses, higher gland cell volume to total gland volume, and enhanced pseudostratification of glandular epithelium. At the same time, there were marginal increases in both gland cell height and percentage of glandular epithelium showing apical, adluminal vacuoles. Interestingly, no significant change could be detected in glandular secretions nor in lumen density. Our report is in agreement with the observations reported by Hertig (1964) and Karow et al. (1971) that increased glandular secretory activity in a conception cycle cannot be detected before days $7-8$ after ovulation. The regulation and purpose of the increase in mitoses in gestational glandular epithelium immediately before implantation remain obscure. However, one should note that, with blastocyst implantation, the glandular epithelium in monkeys undergoes hyperplastic as well as differential changes towards epithelial plaque cell reaction (Enders et al., 1985). It is possible that the observed epithelial mitoses immediately before implantation provide a pool of cells that can be recruited promptly in epithelial plaque cell transformation.

Because changes in the glands of pre-nidatory endometrium are subtle and of mixed nature, the overall pattern of glandular changes was assessed using an equation derived from a dating formula for women developed by $\mathrm{Li}$ et al. (1988). The equation is:

$$
\begin{aligned}
& \text { Luteal gland score [days post-ovulation] }= \\
& \begin{aligned}
7.81-1.43 \times & \log \mathrm{G} 6+2.59 \times \log \mathrm{G} 11-0.033 \\
& \times \mathrm{G} 5-3.70 \times \log \mathrm{G} 9
\end{aligned}
\end{aligned}
$$

Using this equation and the morphometric data obtained, it was found that the gland score was in the range of $5.5-6.4$ (mean 6.1) days for non-fecund, ovulation cycles, and in the range of 4.1 - 5.0 (mean 4.6) days for conception cycles. Apparently the glandular activity in endometrial samples from non-fecund cycles was synchronous with the ovulation age, while in conception cycles it was found to be delayed by about 1.5 days. Since this is only a corollary derived from a hypothetical equation, this result requires cautious interpretation.

Interestingly, the observed morphological characteristics indicative of a marginal delay in the endometrium with increased epithelial mitoses on day 6 of conception fit well with our earlier observations that there is a slight increase in oestradiol/progesterone ratio (Ghosh and Sengupta, 1989a), along with higher nuclear retention of receptors for oestradiol and progestin (Ghosh and Sengupta, 1988b), and low acid phosphatase and higher alkaline phosphatase activities (Sengupta et al., 1988; Ghosh and Sengupta, 1988a) in preimplantation stage endometrium of the rhesus monkey. Several groups have also reported a delay in maturation of human endometrium collected from conception cycles (Sulewski et al., 1980; Wentz et al., 1986; Mazur et al., 1989).

Blastocyst implantation in the human normally begins around 6-7 days after ovulation. In the rhesus monkey, implantation begins on day 8 post-ovulation (Enders and Hendrickx, 1980). Interestingly, 6-8 days post-ovulation corresponds to an interface when a shift in the functional characteristics from the glandular compartment to the stromal - vascular compartments occurs in a normal luteal phase in both human (Ferenczy, 1987) and macaques (Bartelmez, 1957; Brenner and Masler, 1988). Therefore, this period presumably represents a phase during which differential regulation by embryonic signals may be imposed. Sulewski et al. (1980) proposed that endometrium of a conception cycle may be affected even before implantation, that is prior to detection of chorionic gonadotrophin in serum. The present study documents histometric features distinguishing preimplantation stage endometrium on day 6 of gestation in the rhesus monkey. Further studies are necessary to obtain an understanding about the nature of blastocyst-derived putative signals affecting endometrial differentiation during the preimplantation stage in the rhesus monkey.

\section{Acknowledgements}

This study was funded by a programme sponsored by the National Institutes of Health, USA, under the United States held India Rupee Fund (USIF) and the World Health Organization (WHO). We sincerely thank Dr P.F.A.Van Look of the Special Programme of Research, Development and Research Training in Human Reproduction, WHO, Geneva for his continued interest in our research study and the Special Programme's support in providing a travelling grant to D.G. and grant of a WHO Visiting Fellowship to J.S. The WHO Matched Reagents Programme provided the necessary reagents and antisera for performing serum oestradiol and progesterone radioimmunoassays. We thank Mr Ramanand and Mr Sitaram of the Primate Research Facility, and Mr Pradip De and Mr Bholay Ram from the Department of Physiology, AIIMS for their cooperation and technical assistance. We are also thankful to Ms Alexander of the Department of Sterility and Gynaecological Endocrinology, University Hospital, Geneva, Switzerland.

\section{References}

Arronet,G.H., Bergquist,C.A., Parekh,M.C., Latour,J.P.A. and Marshall,K.G. (1973) Evaluation of endometrial biopsy in the cycle of conception. Int. J. Fertil., 18, 220-225.

Bartelmez,G.W. (1957) The phases of the menstrual cycle and their interpretation in terms of the pregnancy cycle. Am. J. Obstet. Gynecol., 74, 931-955.

Bartelmez,G.W., Corner,G.W. and Hartman,C.G. (1951) Cyclic changes in the endometrium of the rhesus monkey (Macaca mulatta). Contrib. Embryol. Carnegie Inst., 34, 99-146.

Bavister,B.D., Boatman,D.E., Leibfried,L., Loose,M. and Vernon,M.W. (1983) Fertilization and cleavage of rhesus monkey oocytes in vitro. Biol. Reprod., 28, 983-999.

Bill,A. (1968) Capillary permeability to and extravascular dynamics of myoglobin, albumin and gammaglobulin in the uvea. Acta Physiol. Scand., 73, 204-219.

Brenner,R.M. and Maslar,I.A. (1988) The primate oviduct and endometrium. In Knobil,E. and Neill,J.D. (eds), The Physiology of Reproduction. Vol. 1. Raven Press, New York, pp. 303-329.

Colburn,P. and Buonassisi,V. (1978) Estrogen-binding sites in endothelial cell cultures. Science, 211, 817-819.

Dallenbach-Hellweg,G. (1987) Functional disturbances of the endometrium. In Fox,H. (ed.), Haines and Taylor Obstetrical and Gynaecological Pathology. Vol. 1. Churchill Livingstone, Edinburgh, pp. $320-339$.

Enders,A.C. and Hendrickx,A.G. (1980) Implantation in non-human primates-I. In Anand Kumar,T.C. (ed.), Non-Human Primate Models for Study of Human Reproduction. Karger, Basel, pp. 99-108.

Enders,A.C., Welsh,A.O. and Schlafke,S. (1985) Implantation in the rhesus monkey: Endometrial responses. Am. J. Anat., 173, 147-169. 
Ferenczy,A. (1987) Anatomy and histology of the uterine corpus. In Kurman,R.J. (ed.), Blaustein's Pathology of the Female Genital Tract. Springer, New York, pp. 257-291.

Finn,C.A. and Porter,D.G. (1975) The Uterus. Publishing Sciences Group Inc., Massachusetts.

Foss,B.A., Horne,H.W. Jr and Hertig,A.T. (1958) The endometrium and sterility. Fertil. Steril., 9, 193-206.

Fraker,P.J. and Speck,J.C. (1978) Protein and cell membrane iodinations with a sparingly soluble chloramide, 1,3,4,6-tetrachloro-3d,6adiphenylglycoluril. Biochem. Biophys. Res. Commun., 80, 849-857.

Ghosh,D. and Sengupta,J. (1988a) A comparative study of endometrial acid phosphatase activity in the mid-luteal phase of the menstrual cycle and in the peri-implantation stage in the rhesus monkey (Macaca mulatta). J. Endocrinol., 116, R7-R9.

Ghosh,D. and Sengupta,J. (1988b) Patterns of estrogen and progesterone receptors in rhesus monkey endometrium during secretory phase of normal menstrual cycle and preimplantation stages of gestation. J. Steroid Biochem., 31, 223-229.

Ghosh,D. and Sengupta,J. (1989a) Estradiol and progesterone levels in the endometrium and the reproductive tract luminal washing during the pre-implantation stages of gestation in the rhesus monkey. Acta Endocrinol., 120, 649-654.

Ghosh,D. and Sengupta,J. (1989b) Endometrial responses to a deciduogenic stimulus of ovariectomized rhesus monkeys treated with oestrogen and progesterone. J. Endocrinol., 120, 51-58.

Ghosh,D., De,P. and Sengupta,J. (1992) Effect of RU 486 on the endometrial response to deciduogenic stimulus in ovariectomized rhesus monkeys treated with oestrogen and progesterone. Hum. Reprod., 7, 1048-1060.

Hay,J.B. and Movat,H.Z. (1979) Hyperemia, stasis, and increase in vascular permeability: New methods for their quantitation. In Movat,H.Z. (ed.), Current Topics in Pathology [Series 68, Inflammatory Reaction]. Springer, Berlin, pp. 33-45.

Hendrickx,A.G. and Enders,A.C. (1980) Implantation in non-human primates-II. In Anand Kumar,T.C. (ed.), Non-Human Primate Models for Study of Human Reproduction. Karger, Basel, pp. 109-115.

Hertig,A.T. (1964) Gestational hyperplasia of endometrium. Lab. Invest., 13, $1153-1191$.

Howard-Jones,N. (1985) A CIOMS ethical code for animal experimentation. WHO Chronicle, 39, 51-56.

Hoyer,L.W. (1981) The factor VIII complex: Structure and function. Blood, 58, 1-13.

Johannisson,E. (1986) Effects of oestradiol and progesterone on the synthesis of DNA and anti-haemophilic factor VIII antigen in human endometrial endothelial cells in vitro: a pilot study. Hum. Reprod., 1, 207-212.

Johannisson,E. (1991) Morphological and histochemical factors related to implantation. Baillière's Clin. Obstet. Gynecol., 5, 191-209.

Johannisson,E., Parker,R.A., Landgren,B.-M. and Diczfalusy,E. (1982) Morphometric analysis of the human endometrium in relation to peripheral hormone levels. Fertil. Steril., 38, 564-571.

Johannisson,E., Landgren,B.-M., Rohr,H.P. and Diczfalusy,E. (1987) Endometrial morphology and peripheral hormone levels in women with regular menstrual cycles. Fertil. Steril., 48, 401-408.

Karow,W.G., Gentry,W.C., Skeels,R.F. and Payne,S.A. (1971) Endometrial biopsy in the luteal phase of the cycle of conception. Fertil. Steril., 22, 482-495.

Klentzeris,L.D., Bulmer,J.N., Warren,A., Morrison,L., Li,T.-C. and Cooke,I.D. (1992) Endometrial lymphoid tissue in the timed endometrial biopsy: Morphometric and immunohistochemical aspects. Am. J. Obstet. Gynecol., 167, 667-674.

Lewis,S.M. and Yin,J.A.L. (1986) Blood volume studies. In Lewis,S.M. and Bayly, R.J. (eds), Radionucleotides in Haematology. Churchill Livingstone, Edinburgh, pp. 198-213.
Li,T.-C., Rogers,A.W., Dockery,P., Lenton,E.A. and Cooke,I.D. (1988) A new method of histologic dating of human endometrium in the luteal phase. Fertil. Steril., 50, 52-60.

Loke,Y.W., King,A. and Drake,B.L. (1993) Leucocytic organization in the endometrium and fallopian tube. In Griffin,P.D. and Johnson,P.M. (eds), Local Immunity in Reproductive Tract Tissues. Oxford University Press, Delhi, pp. 186-204.

Martin,S.A., Perez-Reyes,N. and Mendelsohn,G. (1987) Angioinvasion in breast carcinoma: an immunohistochemical study of factor VIIIrelated antigen. Cancer, 59, 1918-1922.

Mazur,M.T., Duncan,D.A. and Benjamin Younger,J. (1989) Endometrial biopsy in the cycle of conception: histologic and lectin histochemical evaluation. Fertil. Steril., 51, 764-769.

Milligan,S.P. and Mirembe,F.M. (1984) Time course of the changes in uterine vascular permeability associated with the development of the decidual cell reaction in ovariectomized steroid-treated rats. J. Reprod. Fertil., 70, 1-6.

Morris,H., Edwards,J., Tiltman,A. and Emms,M. (1985) Endometrial lymphoid tissue: an immunohistological study. J.Clin. Pathol., 38, 644-652.

Noyes,R.W., Hertig,A.T. and Rock,J. (1950) Dating the endometrial biopsy. Fertil. Steril., 1, 3-25.

Rohr,H.P., Bartsch,G., Oberholzer,M., Reith,A. and Holliger,O. (1978) Stereology. In Johannessen,J.V. (ed.), Electron Microscopy in Human Medicine, Vol. 1. McGraw-Hill, New York, pp. 285-309.

Sengupta,J., Talwar,D., Paria,B.C. and Ghosh,D. (1988) Endometrial phosphatases, $\beta$-glucuronidase and cathepsin D during the menstrual cycle and pre-implantation stages of gestation in the rhesus monkey (Macaca mulatta). Acta Endocrinol., 118, 142-146.

Sengupta,J., Talwar,D., Paria,B.C. and Ghosh,D. (1989) Is there any $\Delta^{5}$-3 $\beta$-hydroxy-steroid dehydrogenase activity in preimplantation embryo of rhesus monkey? Ind. J. Exp. Biol., 27, 417-420.

Sengupta,J., Given,R.L. Talwar,D. and Ghosh,D. (1990) Endometrial response to deciduogenic stimulus in ovariectomized rhesus monkeys treated with oestrogen and progesterone: an ultrastructural study. J. Endocrinol., 124, 53-57.

Sulewski,J.M., Ward,S.P. and McGaffic,W. (1980) Endometrial biopsy during a cycle of conception. Fertil. Steril., 34, 548-551.

Thorgeirsson,G. and Robertson,A.L.,Jr (1978) The vascular endothelium-pathobiological significance. A review. Am. J. Pathol., 93, 803-848.

Wagner,D.D., Olmsted,J.B. and Marder,V.J. (1982) Immunolocalization of von Willebrand protein in Weibel-Palade bodies of human endothelial cells. J. Cell Biol., 95, 355-360.

Wang,J.-D., Fu,Y., Shi,W.-L., Zhu,P.D., Cheng,J., Qiao,J.M., Wang,Y.-Q. and Greene,G.L. (1992) Immunohistochemical localization of progesterone receptors in human decidua of early pregnancy. Hum. Reprod, , 7, 123-127.

Wentz,A.C., Herbert,C.M., Maxson,W.S., Hill,G.A. and Pittaway,D.E. (1986) Cycle of conception endometrial biopsy. Fertil. Steril., 46, 196-199.

Received on April 14, 1993; accepted on June 3, 1993 